


\section{Precarious spectatorship}

\section{MANCHESTER 1824}

Manchester University Press 
Sam Haddow - 9781526138422

Downloaded from manchesterhive.com at $04 / 26 / 2023$ 02:37:57PM 


\section{Precarious spectatorship}

Theatre and image in an age of emergencies

SAM HADDOW

Manchester University Press 
Copyright $\odot$ Sam Haddow 2020

The right of Sam Haddow to be identified as the author of this work has been asserted by him in accordance with the Copyright, Designs and Patents Act 1988.

Published by Manchester University Press

Altrincham Street, Manchester M1 7JA

www.manchesteruniversitypress.co.uk

British Library Cataloguing-in-Publication Data

A catalogue record for this book is available from the British Library

ISBN 9781526138415 hardback

First published 2020

The publisher has no responsibility for the persistence or accuracy of URLs for any external or third-party internet websites referred to in this book, and does not guarantee that any content on such websites is, or will remain, accurate or appropriate.

Cover: Paddy Haddow, Boom (2019)

Typeset by Newgen Publishing UK 